\title{
Pengembangan Usaha Rumah Tangga Melalui Pembuatan Ikan Sarden Sehat Dan Ekonomis Di Kelurahan Rejosari Kecamatan Tenayan Raya Kota Pekanbaru
}

\author{
LILI ERTI $^{1}$, MURNAWATI $^{2}$, TASRIL $^{3}$ \\ ${ }^{1,2,3}$ Universitas Lancang Kuning \\ Jln. Yos Sudarso KM 08 Rumbai Telp. (0761) 52581 \\ E-mail : lilierti@yahoo.com
}

\begin{abstract}
In general, the Rejosari Urban Village, Tenayan Raya Subdistrict in general still had very much free time after they finished working on household routine work. The skills they have for creative food are very minimal because the knowledge they have is very little. Through community service activities which are one of the tri dharma tertiary education activities, it is hoped that they can provide solutions to help provide knowledge to the community, especially the mothers of Rejosari Village, Tenayan Raya District. One effort to improve the creativity and skills of these mothers is by making healthy and economical sardines. The presence of making healthy sardines and traditional and healthy economics is able to provide a solution as a household business so that it can provide potential opportunities especially if it can be developed. One potential is through making healthy and economical sardines. These sardines are liked by children and adults who taste good and healthy. But the texture of the sardines is very soft and tasty because the dough contains fresh tomatoes and shallots and garlic. How to make sardines is of course very easy and practical. The materials needed are also affordable everywhere at a fairly economical price. So anyone can make sardines very economical and very practical, even for beginners. The sweetness and softness of sardines make many people like it and are a favorite side dish. In this service activity, it is expected that public knowledge will increase with the criteria of "good" minimum $75 \%$. As a criterion, at least $75 \%$ of participants have "good" knowledge about this activity. Community service activities are carried out by the method of delivering knowledge through counseling and practice through making healthy and economical sardines.
\end{abstract}

Keywords: Healthy And Economical Sardines, Entrepreneurship

Kecamatan Tenayan Raya merupakan salah satu kecamatan diwilayah Kota Pekanbaru, terdiri atas 98 RW dan 399 RT. Luas wilayah Kecamatan Tenayan Raya adalah $171,27 \mathrm{~km}^{2}$ dengan luas masing-masing kelurahan sebagai berikut: Kelurahan Kulim : $51,50 \mathrm{~km}^{2}$; Kelurahan Tangkerang Timur : $9,92 \mathrm{~km}^{2}$; Kelurahan Rejosari : $11,11 \mathrm{~km}^{2}$; Kelurahan Sail : $98,74 \mathrm{~km}^{2}$

Ibu-ibu Kelurahan Rejosari, Kecamatan Tenayan Raya pada umumnya masih memiliki sangat banyak waktu luang setelah mereka selesai mengerjakan pekerjaan rutin rumah tangga. Keterampilan yang mereka miliki untuk mengkreatifitaskan sebuah bahan pangan sangatlah minim karena pengetahuan yang mereka miliki sangatlah sedikit. Melalui kegiatan pengabdian kepada masyarakat yang merupakan salah satu kegiatan tri dharma perguruan tinggi, maka diharapkan dapat memberikan solusi untuk membantu memberikan ilmu kepada masyarakat khususnya ibu-ibu Kelurahan Rejosari, Kecamatan Tenayan Raya.

$\begin{array}{ccr}\text { Salah } & \text { satu upaya untuk } \\ \text { meningkatkan } & \text { kreativitas } & \text { dan }\end{array}$ keterampilan ibu-ibu tersebut adalah dengan membuat dan ikan sarden sehat dan ekonomis. Kehadiran melalui pembuatan ikan sarden terutama yang tradional dan sehat mampu memberi solusi sebagai lauk yang sehat dan disukai.sehingga dapat memberikan peluang potensial apalagi jika dapat dikembangkan. Ikan sarden merupakan 
salah satu lauk yang disukai keluarga.Ikan sarden memiliki tekstur yang lembut dengan rasa enak yang menggoda.

Cara membuat ikan sarden tentu saja sangat mudah dan praktis. Bahanbahan yang dibutuhkan juga terjangkau dimana-dimana dengan harga yang cukup ekonomis. Jadi siapa saja dapat membuat ikan sarden, bahkan bagi pemula sekali pun. Enak dan lembutnya ikan sarden ini membuat banyak orang jatuh hati dan merupakan lauk favorit keluarga.

Untuk itu kegiatan ini memiliki potensi besar dalam meningkatkan ilmu pengetahuan dan kesejahteraan masyarakat melalui pembuatan ikan sarden sebagai lauk yang disukai dan mampu untuk meningkatkan pendapatan perkapita keluarga sehingga mampu memberi kontribusi dalam memenuhi kebutuhan sehari-hari.

\section{METODE}

Metode yang digunakan dalam pengabdian pada masyarakat ini adalah :

a. Penyuluhan. Penyuluhan merupakan cara yang paling baik untuk memberikan pengetahuan kepada masyarakat .Pelaksanaan kegiatan mencakup penyediaan materi yang berkaitan dengan :

- Pemberian informasi tentang pembuatan ikan sarden kepada masyarakat secara keseluruhan.

- Penjelasan bagaimana tahap pelaksanaan prosespembuatan ikan sarden.

- Memperkenalkan manfaat dari kualitas produk pembuatan ikan sarden yang dihasilkan, merupakan salah satu lauk favorit yang sehat dan ekonomis

- Pembagian materi pengabdian ini dilakukan sebelum penyuluhan dimulai, sehingga diharapkan hasil penyuluhan yang maksimal nantinya.

b. Pelatihan dan Percontohan. Pada kegiatan ini akan diperagakan atau didemonstrasikan bagaimana proses pembuatan ikan sarden. Kegiatan peragaan dilanjutkan dengan pelatihan pada masyarakat.

c. Diskusi dan Konsultasi. Pada saat penyuluhan, pelatihan atau percontohan dan pembinaan dilakukan diskusi-diskusi dan konsultasi antara pelaksanaan kegiatan dengan masyarakat tentang pelaksanaan yang diterapkan dan kendala yang dihadapi, untuk lebih memantapkan hasil kegiatan pengabdian kepada masyarakat ini.

d. Evaluasi. Evaluasi kegiatan ini dilakukan dengan penyebaran kuisioner, sehingga dapat diketahui tingkat pemahaman peserta pada kegiatan pengabdian kepada masyarakat ini.

\section{HASIL}

Sebelum kegiatan dilakukan,
kegiatan diawali
dengan mengadakan survey pendahuluan dan wawancara dengan masyarakat dan aparat Kelurahan Rejosari, Kecamatan Tenayan Raya Pekanbaru serta ditambah dari informasi masyarakat di Kelurahan Rejosari yang memiliki pekerjaan yang bervariasi. Adanya berbagai peluang usaha terutama usaha pembuatan ikan sarden yang dapat dilirik dalam pengembangan industry rumah tangga sebagai sebuah peluang usaha. Adanya peluang usaha yang unik dan menarik maka dapat berpotensi dalam meningkatkan kesejahteraan masyarakat, terutama peningkatan pendapatan perkapita keluarga sehingga mampu memberi kontribusi dalam memenuhi kebutuhan sehari-hari. Kebutuhan bahan baku untuk sebuah usaha telah tersedia sehingga perkembangan diharapkan dapat menjadi peluang usaha mandiri bagi masyarakat.

Pembuatan ikan sarden dengan cara tradisional dan sehat mampu memberi solusi sebagai lauk yang sehat dan disukai.sehingga dapat memberikan peluang potensial apalagi jika dapat dikembangkan. Ikan sarden merupakan salah satu lauk yang disukai keluarga.Ikan 
sarden memiliki tekstur yang lembut dengan rasa enak yang menggoda.

Cara membuat ikan sarden tentu saja sangat mudah dan praktis. Bahan-bahan yang dibutuhkan juga terjangkau dimana-dimana dengan harga yang cukup ekonomis. Jadi siapa saja dapat membuat ikan sarden, bahkan bagi pemula sekali pun. Enak dan lembutnya ikan sarden ini membuat banyak orang jatuh hati dan merupakan lauk favorit keluarga. Adapun hasil kuisioner yang telah diisi oleh peserta kegiatan pengabdian masyarakat, seperti pada tabel berikut ini:

Tabel 1. Hasil Kuesioner Kegiatan Pengabdian kepada Masyarakat

\begin{tabular}{|c|c|c|c|c|}
\hline \multirow{2}{*}{ No. } & \multirow{2}{*}{ Komponen Kuesioner } & \multicolumn{3}{|c|}{ Alternatif Jawaban } \\
\hline & & $\mathrm{T}$ & $\mathrm{N}$ & $Y$ \\
\hline 1. & $\begin{array}{lr}\text { Pengetahuan mengenai } \\
\text { kewirausahaan } \\
\text { peluang usaha }\end{array}$ & $40 \%$ & - & $60 \%$ \\
\hline 2. & $\begin{array}{l}\text { Pengetahuan cara } \\
\text { pembuatan ikan sarden }\end{array}$ & $75 \%$ & - & $25 \%$ \\
\hline 3. & Praktek & - & - & $100 \%$ \\
\hline 4. & $\begin{array}{l}\text { Pengetahuan } \\
\text { narasumber/ pelaksana } \\
\text { kegiatan }\end{array}$ & - & - & $100 \%$ \\
\hline 5. & $\begin{array}{lr}\text { Minat peserta untuk } \\
\text { mengembangkan } \\
\text { sarden }\end{array}$ & $10 \%$ & $15 \%$ & $75 \%$ \\
\hline
\end{tabular}

Ket: $\mathrm{T}=$ Tidak, $\mathrm{N}=$ Netral, $\mathrm{Y}=\mathrm{Ya}$

Sumber: Data Olahan, 2019

Dari rekapitulasi kuisioner diatas maka dapat diketahui bahwa terjadi peningkatan pengetahuan peserta kegiatan mengenai kewirausahaan dan peluang usaha mandiri meningkat dimana peserta yang pada awalnya hanya $60 \%$ saja yang mengetahui menjadi $100 \%$ mengetahui dan memahami mengenai kewirausahaan. Sedangkan pengetahuan mengenai pembuatan ikan sarden meningkat menjadi $100 \%$, dari awalnya hanya $25 \%$ saja yang mengetahuinya. Sedangkan $100 \%$ peserta mengetahui dan memahami proses pembuatan ikan sarden melalui praktek langsung yang didampingi oleh tim pelaksana kegiatan pengabdian. Dan $75 \%$ peserta kegiatan pengabdian berminat untuk menjadikan ikan sarden ini sebagai peluang usaha mandiri.

\section{PEMBAHASAN}

Proses kegiatan pengabdian dilakukan dengan cara demonstrasi dan ceramah, dimana ceramah dilakukan unmtuk menampaikan informasi tentang kewirausahaan dan peluang usaha serta dan cara pembuatan ikan sarden. Secara garis besar hasil kegiatan yang telah dicapai dalam pengabdian masyarakat ini adalah sebagai berikut: Materi kegiatan, mengenai kewirausahaan dan peluang usaha serta dan cara pembuatan ikan sarden pada umumnya dapat dterima dan dapat dipahami serta mendapat respon dari peserta yang ditandai dengan adanya pertanyaan-pertanyaan yang muncul. Berdasarkan sikap dan pertanyaan yang diajukan dapat diketahui bahwa materi pengabdian sangat membantu dalam peningkatan pengetahuan masyarakat. Dari hasil pengabdian ini diharapkan nantinya akan ada tindak lanjut.

Berdasarkan evaluasi dapat diketahui bahwa pada umumnya peserta pengabdian telah memahami tentang kewirausahaan dan peluang usaha serta dan cara pembuatan ikan sarden serta manfaatnya dalam meningkatkan perekonomian keluarga.

\section{SIMPULAN}

Kegiatan terlaksana sesuai dengan tujuan dan rencana. Pada penyelenggaraan kegiatan ini dapat diketahui bahwa ada peningkatan pengetahuan peserta mengenai kewirausahaan dan peluang usaha serta dan cara pembuatan ikan sarden. Program atau kegiatan ini sangat efektif dalam penerapan ilmu pengetahuan dan teknologi bagi masyarakat. Dengan metode yang yang sederhana, pembuatan ikan sarden dapat meningkatkan peluang usaha masyarakat. Selain itu pembuatan ikan sarden dapat dijadikan sebagai sumber penghasilan dalam rangka meningkatkan penghasilan masyarakat.

Berdasarkan pengamatan yang diperoleh dari kegiatan ini, maka perlu dilanjutkan dengan pembinaan yang 
berkesinambungan dan memberi pembekalan mengenai teknik pemasaran.

\section{DAFTAR RUJUKAN}

Busono, T, 2014, Konsep Dasar Kewirausahaan dan Wirausaha, http://silabus.upi.edu/Direktori/FPT K/Teknik_Arsitektur_Perumahan_ (D3)/WIRAUSAHA\%20MATERI \%20terbaru.doc. Diakses pada tanggal 4 September 2015

Herjanto Eddy.(1999). Manajemen Produksi dan operasi. Edisi Kedua. Penerbit PT. Gramedia Widiasarana Indonesia, Jakarta.

Kotler, P. (1997). Manajemen Pemasaran. Diterjemahkan oleh Hendra Teguh dari Buku Marketing Management 9th Ed. Jakarta: Prenhallindo

Susanto,T dan B. Saneto. Teknologi Pengolahan Hasil Pertanian. Surabaya, Indonesia. Winano, F.G., 1993. Pangan, Gizi, Teknologi dan Konsumen. Gramedia Pustaka Utama, Jakarta.

Sudarto, Y. 2000. Budidaya Waluh. Kanisius, Yogyakarta. 